\title{
Carbon-carbon bond cleavage in norbornane derivatives. Convenient route to novel carbocyclic rings
}

\author{
Subrata Ghosh ${ }^{*}$ and Shyamapada Banerjee \\ Department of Organic Chemistry, Indian Association for the \\ Cultivation of Science, Jadavpur, Kolkata - 700 032, India \\ E-mail: ocsg@mahendra.iacs.res.in
}

(received 15 Mar 02; accepted 18 May 02; published on the web 26 May 02)

\begin{abstract}
Various ways of ring opening of norbornane derivatives resulting in the stereoselective synthesis of substituted cyclopentanes, cyclohexanes, fused and bridged rings have been reviewed briefly.
\end{abstract}

Keywords: C-C Bond cleavage, norbornane, cyclopentanes, cyclohexanes, bridged rings

\section{Introduction}

Norbornene and its dihydro derivative norbornane are considerably strained molecules. ${ }^{1}$ Because of the high ground state energy associated with these angle strained molecules, reactions that lead to ring opening proceed readily. The proclivity of the norbornane derivatives to undergo facile ring opening combined with their easy availability through stereoselective Diels-Alder reaction of readily available cyclopentadiene derivatives have made norbornanes useful synthetic intermediates. Ring opening of norbornene derivative can be achieved through scission of either of the four topographically different carbon-carbon bonds viz. 'a', 'b', 'c' or 'd' (Chart 1). With the development of novel reagents and new methodologies for chemo-, regio- and stereoselective reactions it has become possible to realise cleavage of all these bonds. This has resulted in the synthesis of a variety of novel ring systems with defined stereochemistry such as substituted cyclopentanes, cyclohexanes, fused and bridged rings. The objective of this paper is to summarise the various ways ${ }^{2}$ of ring opening of norbornane derivatives with illustrative examples. 


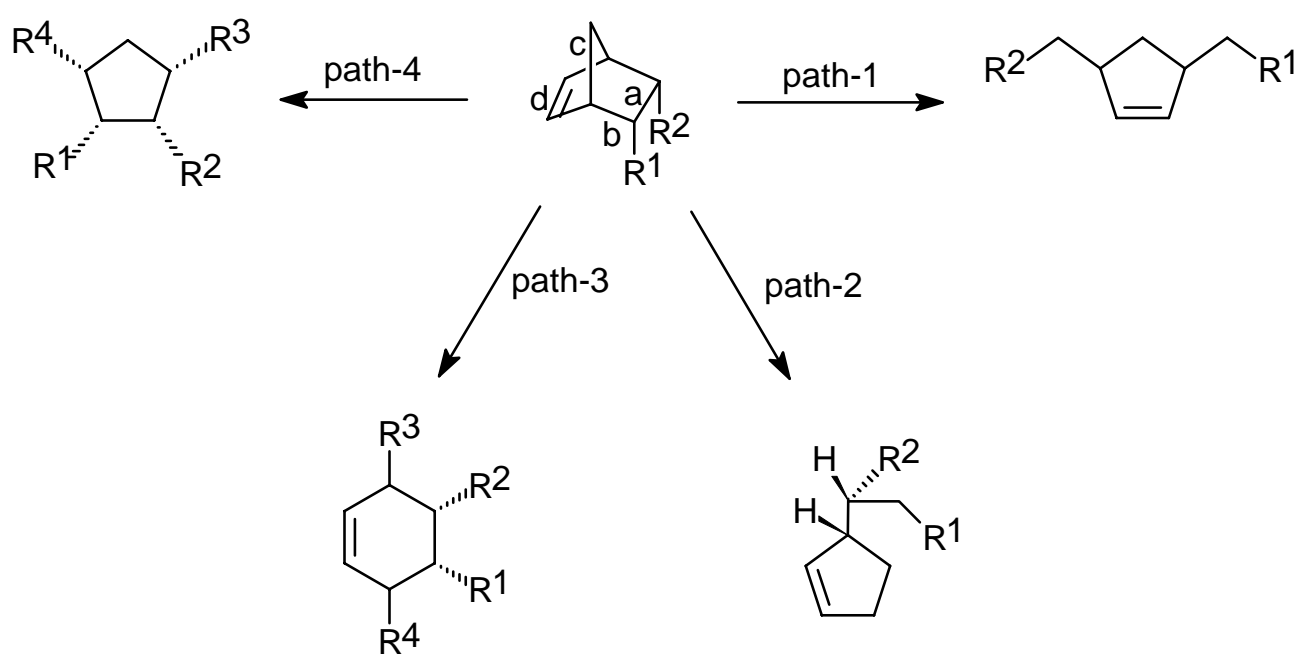

\section{Chart 1}

\section{Cleavage of Bond 'a' (path-1)}

\section{(i) Synthesis of substituted cyclopentanes}

Cleavage of bond 'a' in norbornane derivatives offers an easy access to cis-1,3-disubstituted cyclopentanes. cis-1,3-Disubstituted cyclopentanes have been used as intermediates in the synthesis of terpenoids ${ }^{3}$ as well as in the synthesis of carbocyclic nucleosides. ${ }^{4}$

Ring opening of norbornane derivatives through cleavage of bond 'a' dates back to 1906 when Semmler ${ }^{5}$ demonstrated that fenchone 1a on treatment with sodamide gave the cyclopentane carboxylic acid amide 2a (Scheme-1). Subsequently it was shown that some other 2 -norbornanones ${ }^{6}$ such as $\mathbf{1 b}$ under similar condition produced the ring opened product $\mathbf{2} \mathbf{b}$.

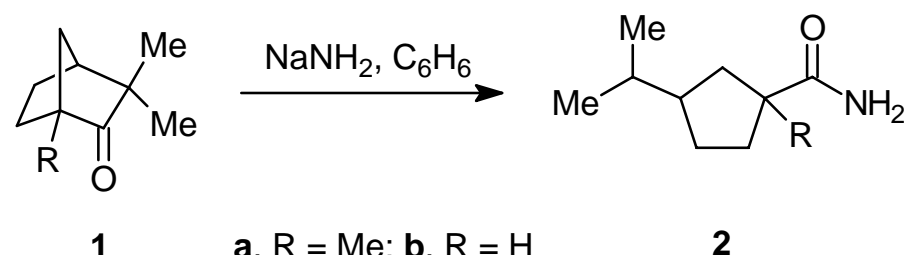

\section{Scheme 1}

The carbon-carbon $\sigma$ bond in succinic ester derivatives has been found to undergo cleavage ${ }^{7}$ when treated with $\mathrm{Na}_{-} \mathrm{NH}_{3}(\mathrm{l})$ at low temperature. This concept was employed by Gassman and Creary $^{8}$ to achieve ring opening of the norbornene derivative 3 to produce cis-1,3-disubstituted cyclopentene derivative $\mathbf{4}$ in excellent yield (Scheme-2). 


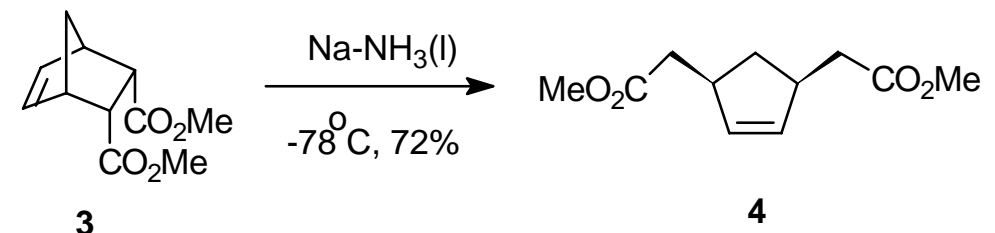

3

4

\section{Scheme 2}

A reductive retrograde aldol C-C bond fission strategy was employed by Katagiri et $\mathrm{al}^{9}$ for ring opening of the norbornane derivative $\mathbf{5}$ to produce stereoselectively the cyclopentane derivative $\mathbf{6}$ in quantitative yield (Scheme-3). The compound $\mathbf{6}$ has been employed for the synthesis of carbocyclic analogue of oxazinomycin.

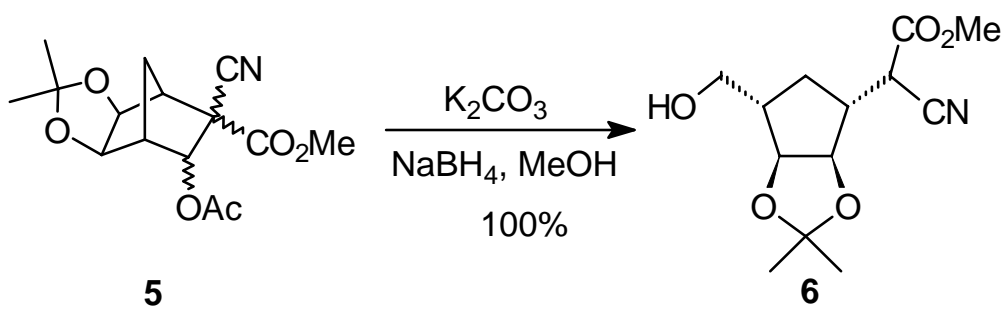

\section{Scheme 3}

1,4-Dicarbonyl compounds when treated with samarium(II) iodide undergo pinacol coupling to produce cyclobutane-1,2-diols. Haque and Ghosh recently demonstrated ${ }^{10}$ that strained molecules having 1,4-dicarbonyl moiety when treated with $\mathrm{SmI}_{2}$ underwent C-C bond cleavage rather than pinacol coupling. Thus, the norbornene derivatives $\mathbf{7 a , b}$ on reaction with $\mathrm{SmI}_{2}$ produced the cis-1,3-disubstituted cyclopentene derivatives 8a,b (Scheme-4) in excellent yields.

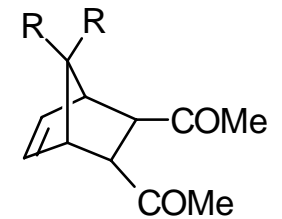

7

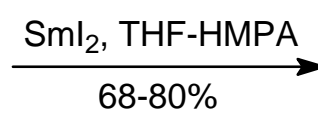

a, $\mathrm{R}=\mathrm{H} ; \mathbf{b}, \mathrm{R}=\mathrm{OMe}$

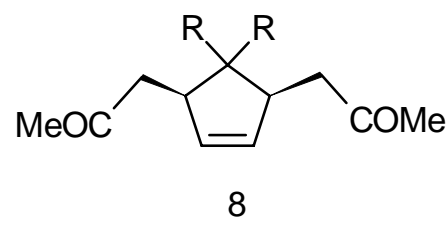

8

\section{Scheme 4}

\section{(ii) Synthesis of bridged rings}

Cleavage of bond 'a' in systems having a ring annulated at the bond 'a' of norbornene, provides a convenient route to novel bridged ring systems. For example, the 1,4-bis mesylates 9a and $\mathbf{9 b}$ 
underwent $^{11}$ a Grob-like fragmentation to afford bicyclo[3.2.1]octene 10a and bicyclo [4.2.1]nonene 10b (Scheme-5), respectively under reductive condition.

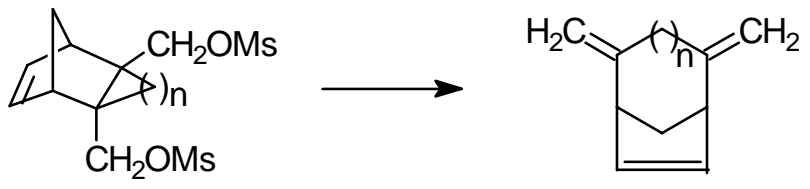

9

$\mathbf{a}, \mathrm{n}=1 ; \mathbf{b}, \mathrm{n}=2$

10

\section{Scheme 5}

Synthesis of eight- ${ }^{12}$ and nine-membered rings has been a long standing problem ${ }^{13}$ because of difficulties arising out of the high degree of ring strain and transannular reaction present in them. An appropriately constructed norbornene derivative on ring opening can provide a facile access to these ring systems. Ghosh et al demonstrated ${ }^{14}$ that when the 1,4-bis mesylates $\mathbf{1 1}$ and $\mathbf{1 3}$ were heated with zinc powder and $\mathrm{NaI}$ in HMPA, Grob fragmentation took place to afford the bridged eight-membered rings 12 and 14, respectively (Scheme-6).

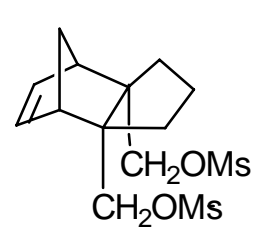

11

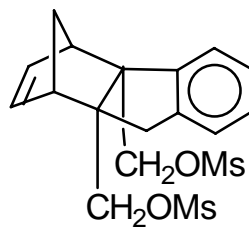

13

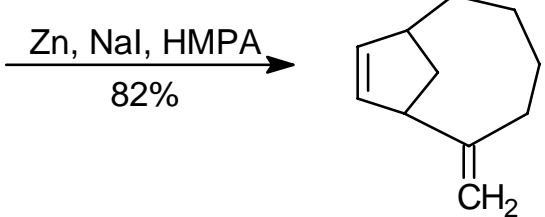

12<smiles>C=C1Cc2ccccc2C(=C)C2C=CC1C2</smiles>

14

\section{Scheme 6}

Appropriately chosen functional groups on the norbornane derivatives and reducing agent give rise to ring opened products with chemodifferentiated functional groups for further elaboration. For example, the dimethyl esters 15a,b when treated with $\mathrm{Na}-\mathrm{NH}_{3}(\mathrm{l})$ at $-55^{\circ} \mathrm{C}$ underwent $\mathrm{C}-\mathrm{C}$ bond cleavage ${ }^{15}$ to afford stereoselectively the bridged eight-membered rings 
16a,b (Scheme-7). The alkene unit in the product 16a was employed for elaboration to the bicyclo[5.3.1] undecane $\mathbf{1 7}$ present in taxane family of bio-active compounds.

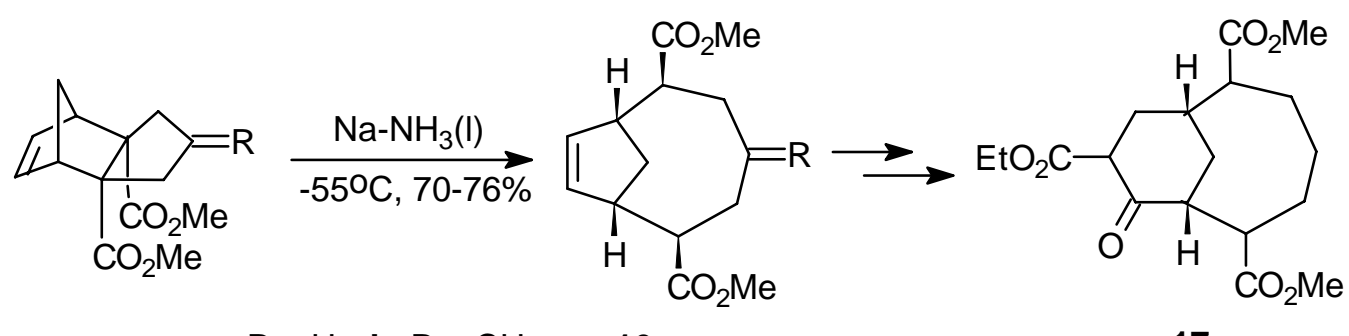

$15 \quad \mathbf{a}, \mathrm{R}=\mathrm{H}_{2} ; \mathbf{b}, \mathrm{R}=\mathrm{CH}_{2} \quad 16$

17

\section{Scheme 7}

Ring strain, functional groups and reducing agent have been found to have profound influence on the reaction course in these systems. The chloro-ester $\mathbf{1 8}$ underwent a smooth radical induced bond fragmentation ${ }^{16}$ when treated with $\mathrm{Bu}_{3} \mathrm{SnH}$ to produce the ring opened product 19 in 88\% yield (Scheme-8). However, C-C bond cleavage did not take place in the relatively less strained chloro-esters 20 and 22 under similar condition and gave exclusively the reduced products 21 and $\mathbf{2 3}$ (Scheme-8), respectively. ${ }^{17}$

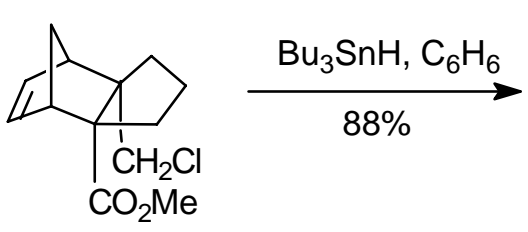

18

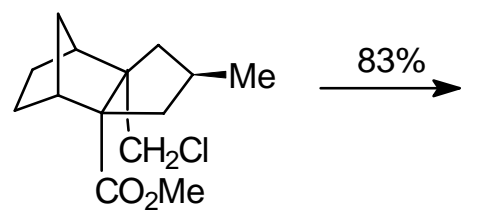

20<smiles>COC(=O)C1C2C=CC(C2)C1C(=O)O</smiles><smiles>C=C1CCCC(C(C)=O)C2C=CC1C2</smiles>

19<smiles>COC(=O)C1CC2CCC1CC(C)C2C</smiles>

21

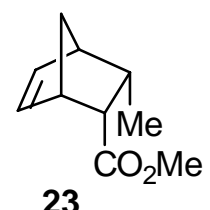

23

\section{Scheme 8}


In contrast to these observations, $\mathrm{SmI}_{2}$ has been found to be very effective in C-C bond fragmentation $^{10}$ in both norbornene and norbornane systems $\mathbf{2 4}$ and $\mathbf{2 6}$ to produce the bridged eight-membered rings 25 and 27 (Scheme-9) in excellent yields.<smiles>COC1(C(C)C)C2C=CC1(C(C)=O)CCC2</smiles>

24<smiles>CCC12CCC(C3CCC1C3)C2(C(C)=O)C(C)=O</smiles>

26
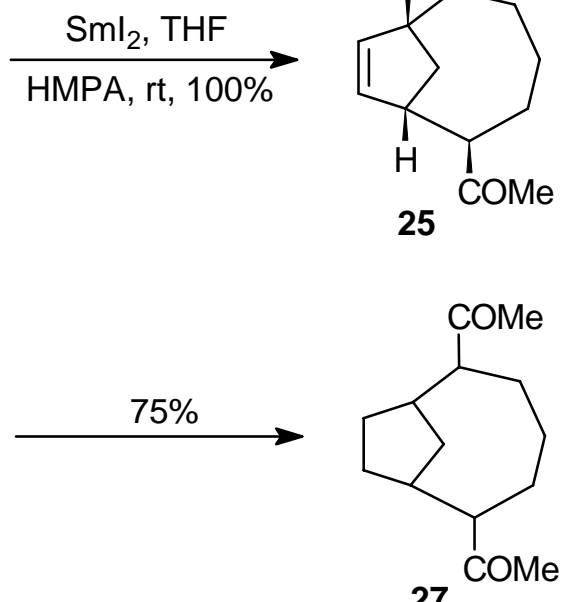

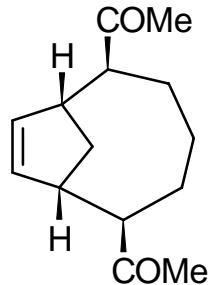

25

27

\section{Scheme 9}

Based on these findings of Haque and Ghosh, Williams et $\mathrm{al}^{18}$ recently showed that bridged nine-membered ring $\mathbf{2 9}$ could also be formed albeit in low yield from the norbornene derivative 28 (Scheme-10).

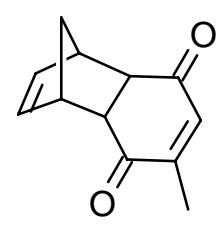

28<smiles>CC(CC(=O)CC1CC2CCC1C2)C(=O)CC1CC1</smiles>

29

\section{Scheme 10}

\section{Cleavage of bond 'b' (Path 2)}

One of the few ways of achieving the cleavage of bond 'b' in norbornane derivatives employs a photochemical $\alpha$-cleavage of cyclic ketones. Thus, $\alpha$-cleavage ${ }^{19}$ of 1 -methyl norbornan-2-one 30 leads to the unsaturated aldehyde 31 (Scheme-11) through abstraction of the syn C-7 hydrogen by the intermediate carbonyl radical. 
Ring opening of norbornane by oxy-anion initiated epoxide cleavage in the epoxy norbornane 32 was reported by Holton and Kennedy ${ }^{20}$ to afford quantitatively the bicyclic lactol 33 (Scheme-12). The coplanarity of the breaking bonds $\left(C_{1}-C_{2}\right.$ and $C_{6}-O$ in the present case) is essential for this cleavage.

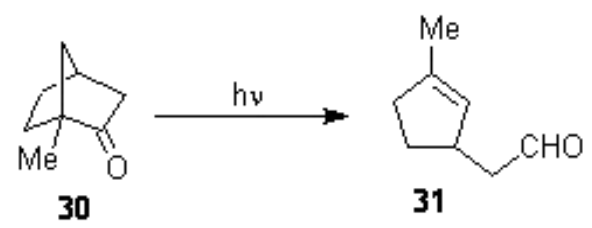

\section{Scheme 11}

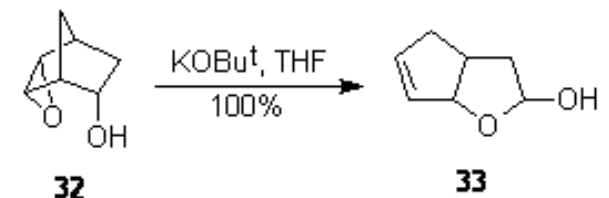

\section{Scheme 12}

Ring opening of norbornene via cleavage of bond 'b' allows stereocontrolled introduction of an alkyl group in the side chain of a substituted cyclopentane. Shimizu and coworkers reported the reductive cleavage ${ }^{21}$ of the norbornanone 35, prepared from the Diels-Alder adduct 34, to afford the cyclopentanone derivative 36 (Scheme-13) in which the Me group on the $\mathrm{C}_{3}$-chain was generated in a totally stereoselective fashion.

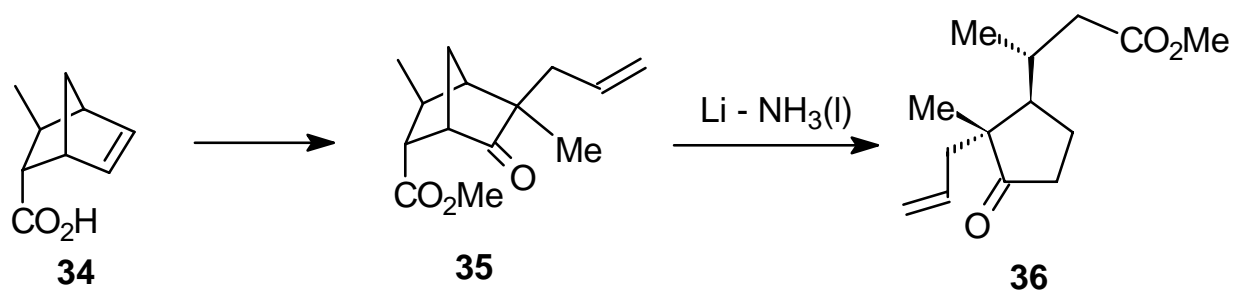

\section{Scheme 13}

In an approach to cyclopentitols, Mehta and Mohal ${ }^{22}$ employed the cleavage of bond 'b' in the 2,7-disubstituted norbornane derivative 37 through a Grob-like fragmentation to afford the substituted cyclopentene derivative $\mathbf{3 8}$ as the major product (Scheme-14). 


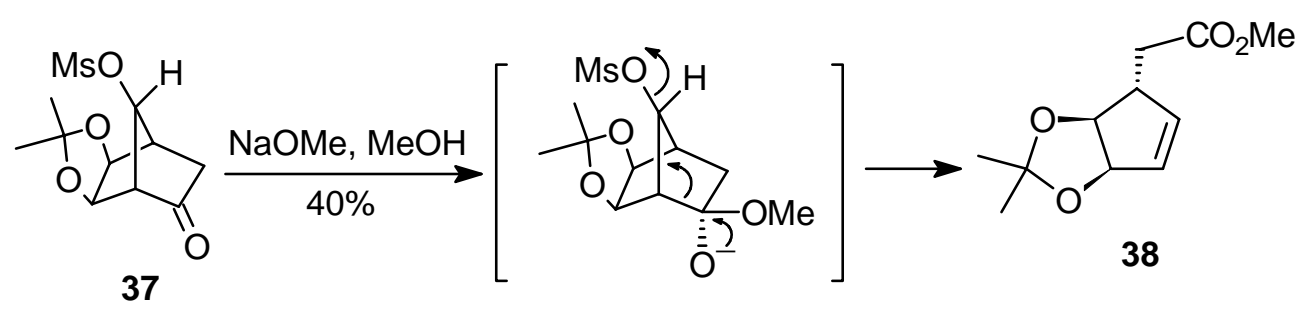

\section{Scheme 14}

\section{Cleavage of Bond ' $c$ ' (Path-3)}

Cleavage of bond ' $c$ ' in norbornanes leads to cyclohexane derivatives. Such cleavage requires a keto-functionality at the 7-position. Gassman et $\mathrm{al}^{23}$ demonstrated that $\mathrm{C}_{1}-\mathrm{C}_{7}$ bond in 7 norbornenone 39 could be readily cleaved via the Haller-Bauer reaction on exposure to base to yield the cyclohexene carboxylic acids $\mathbf{4 0}$ and $\mathbf{4 1}$ (Scheme-15).<smiles>O=C1C2C=CC1CC2</smiles>

39

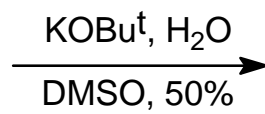<smiles>O=C(O)C1CC=CCC1</smiles>

40<smiles>O=C(O)C1=CCCCC1</smiles>

41

\section{Scheme 15}

House and Cronin ${ }^{24}$ showed that cleavage of bond ' $c$ ' in a 7-norbornanone derivative, tricyclo[5.2.1.0 $0^{2,6}$ ]dec-8-en-10-one 42, could be achieved through Haller-Bauer reaction to provide stereoselectively the cis-hydrindane derivative $\mathbf{4 3}$ (Scheme-16).

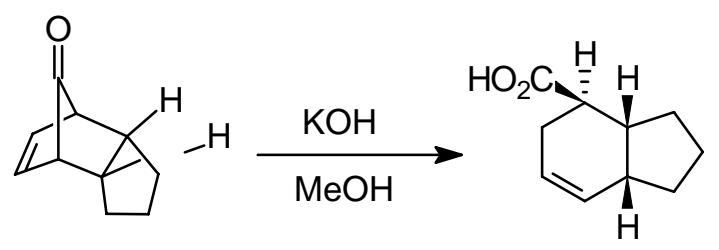

\section{Scheme 16}

Recently, Mehta and coworkers ${ }^{25-29}$ investigated the regioselectivity in the cleavage of unsymmetrical tricyclo[5.2.1.0 $0^{2,6}$ dec-8-en-10-one derivatives using Haller- Bauer reaction for 
the synthesis of highly functionalised cis-hydrindanes (Scheme-17). Thus, the endotricyclo[5.2.1.0 $0^{2,6}$ ]decene derivatives $\mathbf{4 4}$ on treatment with aq. $\mathrm{NaOH}$ followed by esterification provided a number of cis-hydrindanes 45 . The regioselectivity observed during the cleavage in these substrates appears to arise through the influence of the neighbouring C-3 electron withdrawing substituent. The hydrindane derivatives obtained in this way have been elegantly employed for the total synthesis of natural products such as coronofacic acid, ${ }^{25,26}$ pumiliotoxin, ${ }^{27}$ a primnatriene-type sesquiterpene ${ }^{28}$ and structures ${ }^{29}$ related to natural products.

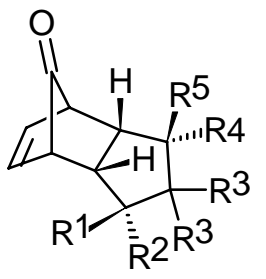

44

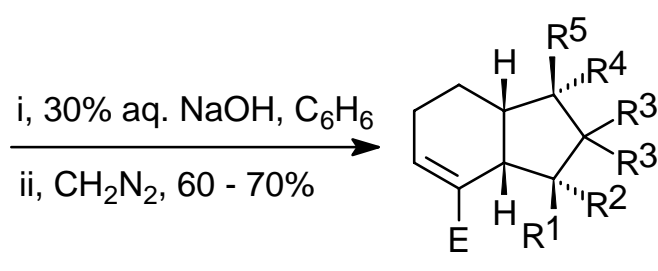

$45 \mathrm{E}=\mathrm{CO}_{2} \mathrm{Me}$
a, $R^{1}=R^{2}=R^{3}=H, R^{4}, R^{5}=O$
b, $R^{1}=M e, R^{2}=R^{3}=H, R^{4}, R^{5}=O$
c, $R^{1}=R^{3}=H, R^{2}=M e, R^{4}, R^{5}=O$
d, $R^{1}=R^{2}=M e, R^{3}=H, R^{4}, R^{5}=0$
e, $R^{1}=R^{2}=R^{5}=H, R^{3}=M e, R^{4}=O H$

\section{Scheme 17}

Haller-Bauer cleavage of 7-norbornenone derivative $\mathbf{4 6}$ having an eight-membered ring has also been employed ${ }^{30}$ for the synthesis of cis-bicyclo[6.4.0]dodecane 47 present in taxanes (Scheme-18).
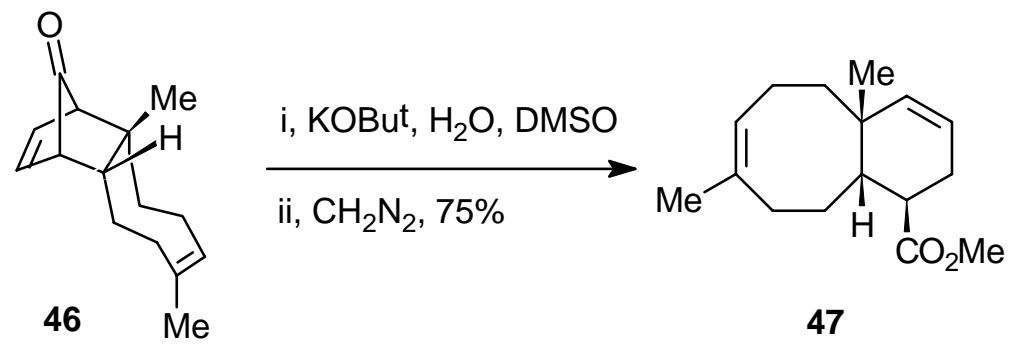

47

\section{Scheme 18}

\section{Cleavage of bond 'd' (Path-4)}

Reaction of norbornene derivatives with a metal-carbene complex leading to ring opening (popularly known as ring opening metathesis) and subsequent coupling with an acyclic alkene (cross metathesis) provides a novel way of cleaving olefinic bond in norbornene derivatives. 
Blechert et $\mathrm{al}^{31}$ demonstrated that symmetrical norbornenes such as $\mathbf{4 8}$ in presence of a slight excess of terminal alkene produced only the tetrasubstituted cyclopentene 49 (Scheme-19) in excellent yield using the Ru-catalyst 50. Regioselectivity in ring opening of unsymmetrical norbornenes during ring opening metathesis was also observed. Thus, reaction of dicyclopentadiene $\mathbf{5 1}$ with allysilane afford a 3:1 mixture of the two regioisomeric products 52 and 53 (Scheme-20). The advantage of this ring opening cross metathesis reaction is the conversion of norbornene derivatives with defined configuration into substituted cyclopentanes of defined configuration.

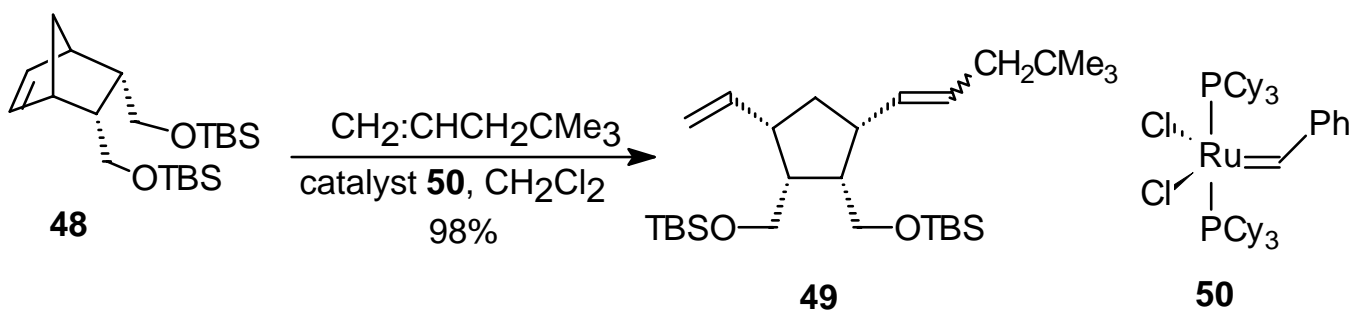

\section{Scheme 19}

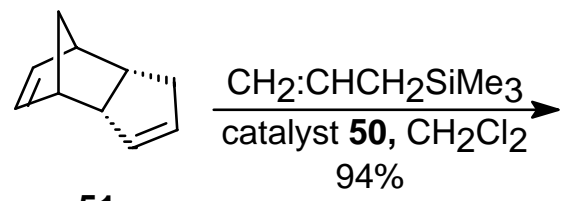

51

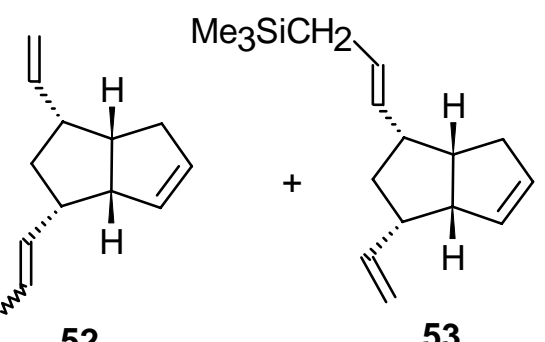

53

\section{Scheme 20}

A tandem ring opening-ring closing metathesis in the norbornane derivatives has been of great use in the synthesis of multicyclic compounds. For example, Grubbs and coworkers have shown that the norbornene derivative $\mathbf{5 4}$ on heating in benzene with a catalytic quantity of the catalyst 50 afforded the fused tricycle 55 (Scheme-21) via ring opening of the norbornene ring followed by a double ring closing metathesis.

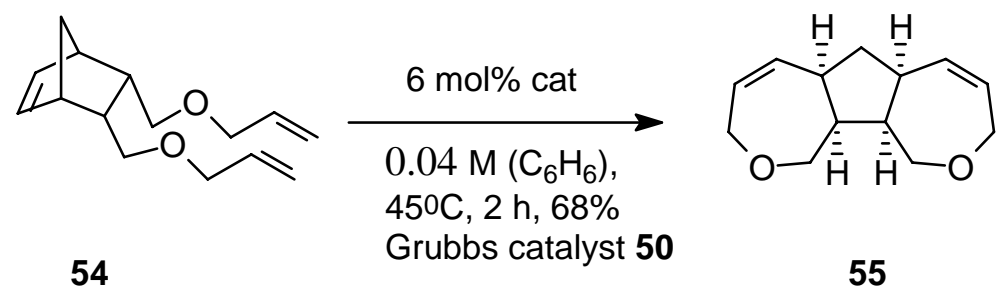

\section{Scheme 21}


Stragies and Blechert ${ }^{33}$ have accomplished the synthesis of [n.3.0]bicycles using a domino process involving ring closing-, ring opening- and cross metathesis. Thus, the norbornene derivatives $\mathbf{5 6}$ on treatment with a catalytic quantity of the Ru-catalyst $\mathbf{5 0}$ in the presence of a terminal alkene, allyl trimethly silane or ethylene, provided the bicycles 57 (Scheme-22). Higher yields of the products were obtained with Schrock's molybdenum complex $\mathrm{PhMe}_{2} \mathrm{CCH}=\mathrm{Mo}=\mathrm{N}\left[2,6-\left(\mathrm{isoPr}{ }_{2} \mathrm{C}_{6} \mathrm{H}_{3}\right]\left[\mathrm{OCMe}\left(\mathrm{CF}_{3}\right)_{2}\right]_{2}\right.$ The facile synthesis of the carbocyclic eight-membered ring $56(n=3)$ is noteworthy as this ring system is particularly difficult to construct by other methods including ring closing metathesis.

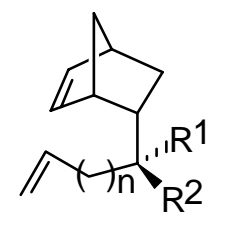

56

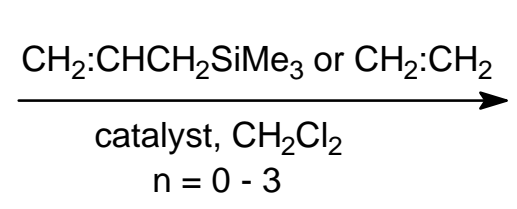$$
n=0-3
$$

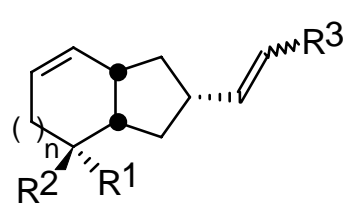

$57 \quad 33-88 \%$ with Ru catalyst

\section{Scheme 22}

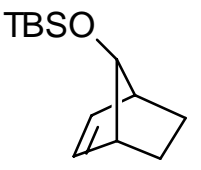

58

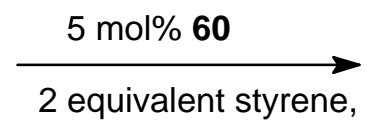

$\mathrm{C}_{6} \mathrm{H}_{6}, 22{ }^{\circ} \mathrm{C}, 57 \%$

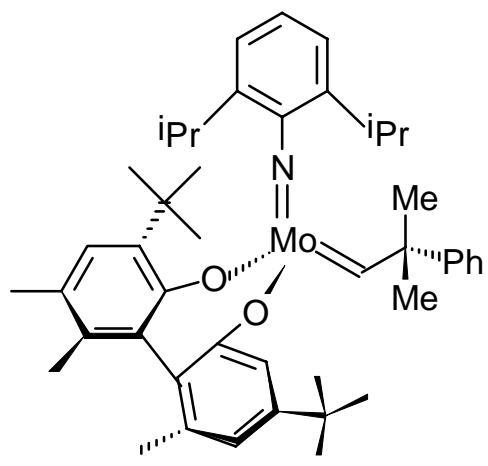<smiles>C=CC1CCC(/C=C/c2ccccc2)C1O[Sb]</smiles>

59, ee $96 \%$

60

\section{Scheme 23}

Ring opening of norbornene through a sequence of ring opening metathesis and cross metathesis using a chiral molybdenum carbene complex has recently been shown by Hoveyda et $\mathrm{al}^{34}$ to be an extremely efficient process for enantioselective synthesis of substituted cyclopentanes. A representative example involves treatment of the norbornene derivative $\mathbf{5 8}$ in 
benzene solution with 2 equivalent of styrene in the presence of $5 \mathrm{~mol} \%$ of the catalyst $\mathbf{6 0}$ at $22^{\circ} \mathrm{C}$ to afford the substituted cyclopentane 59 (Scheme-23) in 57\% yield with 96\% ee. Even $>98 \%$ ee was observed during such transformation when vinyl silane was used for cross metathesis.

\section{Conclusions}

The results discussed here show that $\mathrm{C}-\mathrm{C}$ bond scission of norbornane derivatives has proven to be an efficient approach for the stereoselective synthesis of substituted cyclopentanes, cyclohexanes, fused rings and novel bridged rings. Since norbornene derivatives can be prepared stereoselectively through Diels-Alder reaction of cyclopentadiene derivatives, synthetic strategy involving Diels-Alder cycloaddition and subsequent fragmentation provides great application opportunities in organic synthesis.

\section{Acknowledgements}

Financial support from CSIR, New Delhi through Grant No. 01(1625)/EMR-II is gratefully acknowledged. SPB thanks CSIR for a Senior Research Fellowship.

\section{References and Notes}

1. Engler, E.M.; Andose, J.D.; Schleyer, P. von R. J. Am. Chem. Soc. 1973, 95, 8005.

2. Ring opening that involves simultaneous bond breaking-bond formation (as in sigmatropic rearrangement) or two $\mathrm{C}-\mathrm{C}$ bond cleavage (retro Diels-Alder reaction) and oxidative cleavage of olefin or olefin derived functional groups has not been covered here.

3. Curran, D.P.; Chen, M. Tetrahedron Lett. 1985, 26, 4991.

4. Crimmins, M.T. Tetrahedron 1998, 54, 9229.

5. Semmler, F.W. Ber. 1906, 39, 2577.

6. Hamlin, K.E.; Weston, W.A. Org. React. 1957, 9, 1.

7. Bertele, E.; Boos, H.; Dunitz, J.D.; Elsinger, F.; Eschenmoser, A.; Felfer, I.; Gribi, H.P.; Gschwend, H.; Meyer, E.F.; Pesaro, M.; Scheffold, R. Angew. Chem., Int. Ed. 1964, 3, 490.

8. Gassman, P.G.; Creary, X. J. Chem. Soc., Chem. Commun. 1972, 1214.

9. Katagiri, N.; Tomura, M.; Haneda, T.; Kaneko, C. J. Chem. Soc., Chem. Commun. 1987, 1422.

10. Haque, A.; Ghosh, S. J. Chem. Soc., Chem. Commun. 1997, 2039; Ind. J. Chem. 2001, 40B, 930.

11. Martin, H.D.; Heller, C. Monatsh. Chem. 1979, 110, 1271; CA, 92 : 75935s. 
12. For a recent review on the synthesis of eight-membered rings see : Mehta, G.; Singh, V. Chem. Rev. 1999, 99, 881.

13. Illuminati, G.; Mandolini, L. Acc. Chem. Res. 1981, 14, 95.

14. Ghosh, S.; Karpha, A.; Saha, G.; Patra, D. Tetrahedron Lett. 1992, 33, 2363; Ghosh, S.; Sarkar, S.; Saha, G. J. Chem. Soc., Perkin Trans. 1, 1993, 2281.

15. Saha, G.; Bhattacharya, A.; Saha Roy, S.; Ghosh, S. Tetrahedron Lett. 1990, 31, 1483; Saha, G.; Karpha, A.; Saha Roy S.; Ghosh, S. J. Chem. Soc., Perkin Trans. 1 1992, 1587.

16. Sarkar, S.; Ghosh, S. Tetrahedron Lett. 1993, 34, 2987.

17. Sarkar, S.; Ghosh, S. Tetrahedron 1994, 50, 921.

18. Williams, D.B.G.; Blann, K.; Holzapfel, C.W. J. Chem. Soc., Perkin Trans. 1 2001, 219.

19. Yates, P.; Loutfy R.O. Acc. Chem. Res. 1975, 8, 209.

20. Holton, R.A.; Kennedy, R.M. Tetrahedron Lett. 1984, 25, 4455.

21. Shimizu, I.; Matsuda, N.; Noguchi, Y.; Zako, Y.; Nagasawa, K. Tetrahedron Lett. 1990, 31, 4899.

22. Mehta, G.; Mohal, N. Tetrahedron Lett. 1999, 40, 5791.

23. Gassman, P.G.; Lumb, J.T.; Zalar, F.V. J. Am. Chem. Soc. 1967, 89, 946.

24. House, H.O.; Cronin, T.H., J. Org. Chem. 1965, 30, 1061.

25. Mehta, G.; Praveen, M. J. Chem. Soc., Chem. Commun. 1993, 1573.

26. Mehta, G.; Reddy, D.S. Tetrahedron Lett. 1999, 40, 991.

27. Mehta, G.; Praveen, M. J. Org. Chem. 1995, 60, 279.

28. Mehta, G.; Reddy, D.S. Synlett 1996, 229.

29. Mehta, G.; Reddy, D.S. Synlett 1997, 612.

30. Mehta, G.; Reddy, K.S.; Kunwar, A.C. Tetrahedron Lett. 1996, 37, 2289.

31. Schneider, M.F.; Lucas, N.; Velder, J.; Blechert, S. Angew. Chem., Int. Ed. 1997, 36, 257.

32. Zuercher, W.; Hashimoto, M.; Grubbs, R.H. J. Am. Chem. Soc. 1996, 118, 6634.

33. Stragies, R.; Blechert, S. Synlett 1998, 169.

34. La, D. S.; Ford, J. G.; Sattely, E. S.; Bonitatebus, P. J.; Schrock, R.R.; Hoveyda, A.H. J. Am. Chem. Soc. 1999, 121, 11603. 